\title{
HOW PEOPLE PERCEIVE RESILIENCE OF HIMALAYAN PHEASANTS, PHASIANIDAE, IN RELATION TO CLIMATE WARMING IN EASTERN HIMALAYA
}

\author{
Bijoy Chhetri ${ }^{1,2} \mathbb{D}$, Hemant K. Badola ${ }^{1,3, *}$, Sudip Barat ${ }^{4}$ \\ ${ }^{1}$ G.B. Pant National Institute of Himalayan Environment and Sustainable Development, India \\ *e-mail: hkbadola@gmail.com \\ ${ }^{2}$ Shri Ramasamy Memorial University Sikkim, India \\ ${ }^{3}$ Aditya Doonshire Apartments, Sailok Phase 2, GMS Road, Dehradun, India \\ ${ }^{4}$ University of North Bengal, India
}

Received: 04.12.2020. Revised: 18.06.2021. Accepted: 21.06.2021.

\begin{abstract}
Conceptual frameworks of climate change impact on the Himalayan biodiversity have given high emphasis to understand the linkages between indigenous people and their environment. Existing literature lacks climate change ramification on Himalayan biodiversity due to a deficit of long-term data. Therefore, perception tools are used to illuminate climate change impacts on Himalayan biodiversity by the local people's knowledge regarding their environment. We used a snowball technique to understand the indigenous knowledge, responses, and their perception of Himalayan pheasants (Ithaginis cruentus, Lophophorus impejanus, Lophura leucomelanos, and Tragopan satyra) with climate change in Eastern Himalaya. We carried out a case study by taking people's perception in and around the Khangchendzonga Biosphere Reserve. The results indicated that climate warming is more pronounced in the local premise of Himalaya, which has significantly affected the Himalayan pheasants. The questionnaire reliability was tested with Cronbach's alpha. The value was quite high despite the small number (three variables) of items. Having established the scale reliability and validity of the data, linear regression analysis found appropriate to judge the range shift of pheasants. The regression demonstrated the goodness of fit was quite acceptable considering the F value; climate warming significantly influenced the overall pheasant range shift as revealed by the data obtained from the respondents $(\mathrm{p}<0.001)$. This study will be an insight into the climate change impacts on Himalayan biodiversity and will give more focus to the threatened and narrow ranged endemic species of the Himalayas before they go to the verge of extinction.
\end{abstract}

Key words: climate change, conservation, Galliformes, endemic species, indigenous knowledge, restricted range

\section{Introduction}

Indigenous people are closely related to the natural elements and phenomena of the environment (Vogt et al., 2002; Badola, 2017). This information can be used by scientists and policy-makers to develop appropriate action plans for landscape management in the future perceptive. Understanding the local perception of wildlife conservation is a crucial part of conservation directives for designing appropriate policies and conservations (Jyrwa et al., 2020). Conservation programmes often focus to minimise human-wildlife conflicts and minimise the unsustainable use of forest resources in highly complex socio-economic environments, where local communities play a pivotal role in both the trade chain and the conservation actions implemented (Bennett, 2016; Sánchez-Mercado et al., 2020). Therefore, native people's perception of changes in their ecosystem with time is crucial for understanding the ongoing biodiversity process and patterns, and climate change trends of the landscape. Most of the indigenous and traditional ecological knowledge is vanishing without proper documentation, which may help to get a better understanding of species range shift data (Chhetri et al., 2018) and phenology shift data (Barnard \& Thuiller, 2008; Socolar et al., 2017) concerning climate change. Similarly, in many developed countries, a loss of indigenous knowledge and traditional culture has created a gap between people and nature.

Nowadays, modernisation, new technology, and anthropogenic pressure as the pursuit of the betterment of our lifestyle have also accelerated the loss of indigenous knowledge. However, hunting and fishing techniques of Arctic people mostly depend on stable icy landscapes that are under threat by the current rate of temperature, which is predicted to warm more rapidly than the global mean temperature (Pachauri et al., 2014). Climate warming is critically viewed in response to the loss of alpine biodiversity (Gentili et al., 2015). In mountain regions, upward movements of plant species and timberlines are predicted to reach «sky islands» (Gottfried et al., 2012; Pandey et al., 2018). The increase in mean annual temperatures is not uniform around the globe. Although, the highest average temperatures are experienced in the 
mountain ecosystem of the Himalayas (Pachauri et al., 2014). Furthermore, the Himalayan biodiversity may come under threat from the current pace of climate change in the Eastern Himalayas (Chhetri et al., 2018; Subba et al., 2018; Singh et al., 2020).

Rural people have an in-depth understanding of their traditional ecological knowledge, which is passed down through adaptive ways over generations by cultural transmission about their local climate variability information (Berkes et al., 2000). Therefore, «local perceptions» are considered as a tool for identification and interpretation of long-term observation and concepts of local people's information (Vignola et al., 2010). Mostly, research work on the perceptions for climate change taking the prominent factors like temperature and rainfall (Byg \& Salick, 2009; Fisher et al., 2010) and even weather data are frequently utilised for the validation by villagers' perception (Fisher et al., 2010) and perception of vulnerability assessment by climate variability (Saroar \& Routray, 2012).

The perception of expert knowledge can be an effective tool to address knowledge gaps in the absence of adequate data, especially in the high mountain regions (Chamberlain et al., 2016). There is a dearth of good data on birds from the high-altitude regions of the world. However, only a few countries have reliably appropriate long-term monitoring data for high altitude species (Maggini et al., 2011). The Himalayan region is considered a data-limited region. The perception-based information plays an important role to fill knowledge gaps in the data deficit regions, like the Himalayas, for better understanding biodiversity-related queries (Ives, 2004; Chaudhary et al., 2011; Negi et al., 2017). Furthermore, the alliance between indigenous and scientific knowledge may give a new vision of climate change impact on biodiversity.

By specifically aiming the assessment of perceived conservation threats to Himalayan pheasants and their resilience to the warming climate, our present study using a perception tool focuses on the four Sikkim Himalayan pheasant species, namely Ithaginis cruentus Hardwicke, 1821 (Blood pheasant), Lophophorus impejanus Latham, 1790 (Himalayan Monal), Lophura leucomelanos Latham, 1790 (Kalij pheasant), and Tragopan satyra Linnaeus, 1758 (Satyr Tragopan). The objectives of the study were (i) to assess climate change impacts on the resilience of Himalayan pheasants in Sikkim Himalaya, and (ii) to understand how Himalayan pheasants cope with climate warming by molding themselves into range shift and phenology shift using multivariate analysis.

\section{Material and Methods \\ Study area}

The perception-based survey was done in and around villages in the transition zone of the Khangchendzonga Biosphere Reserve (core zone, $1784 \mathrm{~km}^{2}$ : Khangchendzonga National Park (KNP), a UNESCO World Heritage Site, inscribed in July 2016) in Sikkim, Eastern Himalaya, covering the northern and western regions (Fig. 1). The highbiodiversity rich Khangchendzonga Biosphere Reserve (KBR), a part of the World's Network of biosphere reserves inscribed by UNESCO in July 2018 (Pandey et al., 2018), covers $2931.12 \mathrm{~km}^{2}$ total spatial area, including $835.92 \mathrm{~km}^{2}$ of buffer and $311.20 \mathrm{~km}^{2}$ of transition zones. It extends between $27.25000000^{\circ}-27.95000000^{\circ} \mathrm{N}$ and $88.03305556^{\circ}-$ $88.66694444^{\circ} \mathrm{E}$, making international boundaries with China and Nepal (Badola \& Subba, 2012).

The intensive study area is located under high altitude gradients, with no human settlement there in the core and buffer zone. We gathered in-field perception-based information by interviewing those who are directly or indirectly associated with the KBR such as foresters, Himal Rakshaks (voluntary protectors), village elders, local guides, local porters, and pack owners. They were mostly movable participants approached in the KBR wilderness. Therefore, we used a semi-structured questionnaire followed by a snowball technique to procure the data from the 120 respondents.

In addition, we also approached the nearby villages of the trail of North Sikkim (Tholung-Kisong lake trail) and West Sikkim (Yuksom-Dzongri trail) of the KBR (Fig. 1). In this regard, the majority of respondents of the interviews were males compared to the females (less than 3\%) because it was found that males were more associated with the forest and having better knowledge about the biodiversity of the study area. The respondents' age was in the range of 35-90 years. The questionnaire format consisted of a series of the following attributes: (i) What was the availability of the Himalayan pheasants in KBR?; (ii) What was the past status of poaching and hunting of the Himalayan pheasants by forefathers?; (iii) What were the uses of Himalayan pheasants by their forefathers for religious, decoration, healer, hunting and ethno-medicine purposes?; (iv) Who are the predators of the Himalayan pheasants?; (v) What is respondent's experience of climate warming in their locality?; (vi) Which range shift of the Himalayan pheasants they perceive?; (vii) What are the factors of range shift of Himalayan pheasants?; (viii) How do they perceive the phenology shifts of Himalayan pheasants? We analysed these data to quantify the percentage of the respondents for each attribute. 


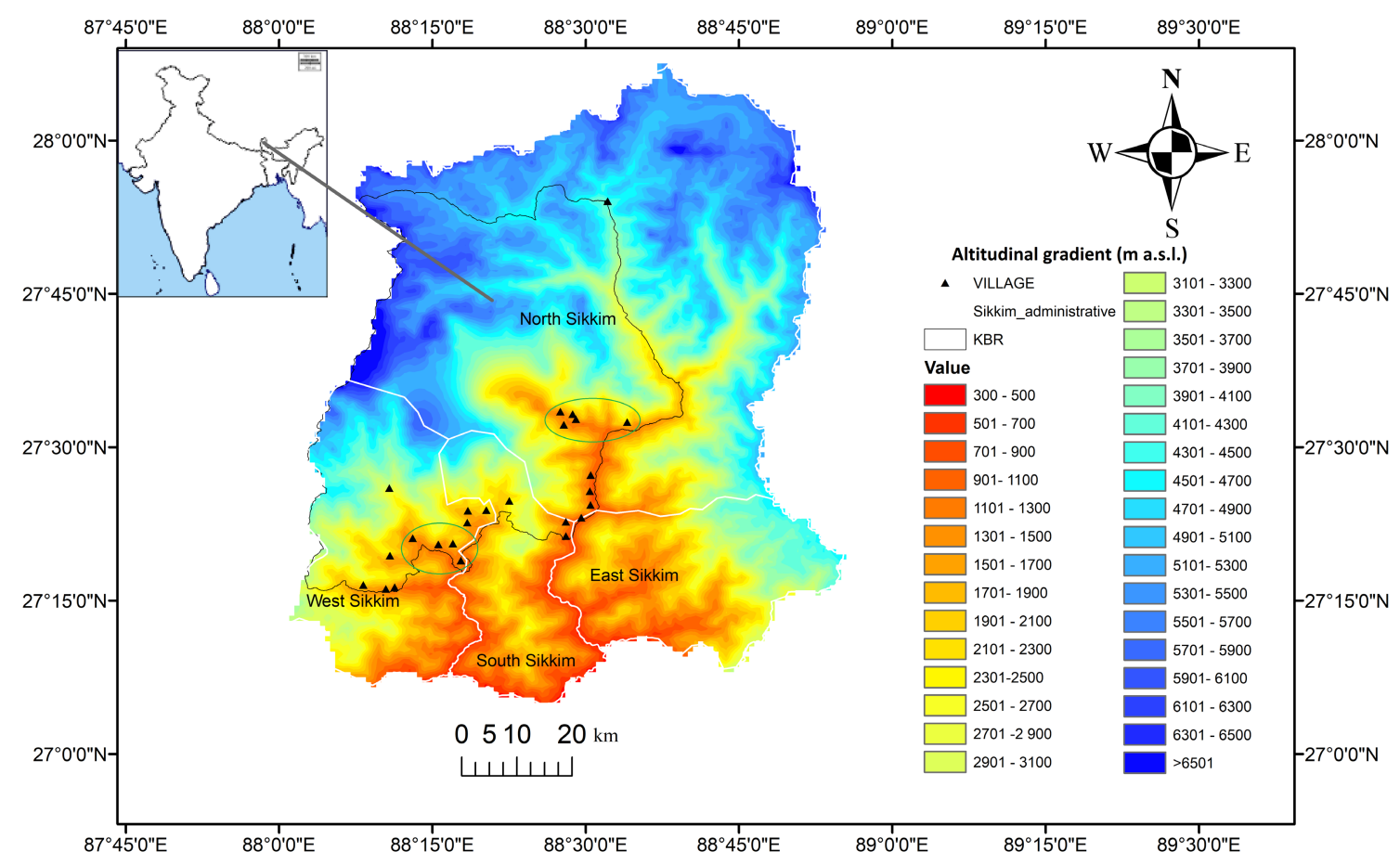

Fig. 1. The map of the Khangchendzonga Biosphere Reserve, Sikkim Himalaya. Villages (triangles) depicted within the two green ovals were targeted for the perception study.

\section{Analytical analysis}

From the procured data, we quantified the percentage of the responses and quantified the Priority Index using the formulas:

$$
\begin{gathered}
R P=\frac{N_{R R}}{N_{T N R}} \times 100 \%, \\
P I=\frac{N_{\text {SCORE }}}{T_{\text {SCORE }}},
\end{gathered}
$$

where RP is the response proportion; $\mathrm{N}_{\mathrm{RR}}$ is the number of respondents who answered the question; $\mathrm{N}_{\mathrm{TNR}}$ is the total number of respondents; PI is the Priority Index; $\mathrm{N}_{\mathrm{SCORE}}$ is the number of scores applied by respondents for a certain question; $T_{\text {SCORE }}$ is the sum of applied scores. The maximum possible value for each question was 10 scores.

\section{Statistical analysis}

Climate warming emerges with important challenges for avian species. To cope up with high temperatures, birds expect to shift to colder regions or shift their early phenology (Socolar et al., 2017). By taking this approach for statistical analysis, we used a multivariate analysis to relate a set of explanatory variables (range shift and phenology shift) with one dependent variable, climate warming. For this study of targeted Himalayan pheasants, we used data from local perception, adopted by Bhattacharya \& Pradhan (2018).

After gathering the data (climate warming, range shift, and phenology shift of the Himalayan pheasants), we used various descriptive statistics to quantify the mean, mode, median, and normality of data by the Kolmogorov-Smirnova test and Shapiro-Wilk test using SPSS software ver. 21 along with mean and standard error using $\mathrm{R}$ ver. 3.6.2 ( $\mathrm{R}$ Core Team, 2019). The collected data of the climate change, range shift, and phenology shift of targeted pheasants from the respondents were framed into a 4-point scale $(0$ - no climate change, 1 - low climate change, 2 - moderate climate change, 3 - high climate change) for statistical analysis, adopted by Bhattacharya \& Pradhan (2018).

For establishing reliability constructs of the questionnaire, Cronbach's alpha value was used following the similar approach of Gliem \& Gliem (2003). A factor analysis was used to establish the scale dimensionality. For the questionnaire appropriateness, we used the Barlett Test of Sphericity (BTS), KaiserMeyer-Olkin test (KMO), and Principal Component Analysis (PCA) following the similar approach of Olawale \& Garwe (2010) and Bhattacharya \& Pradhan (2018). BTS provides the correlation matrix among the variables in the datasets. We used the KMO test to quantify sample size adequacy (Norusis, 1985). The value of the KMO test ranges between $0-1$. If the value is higher than 0.60 , it demonstrates that the factor analysis of the variables is appropriate (Crane et al., 1991; Olawale \& Garwe, 2010). Also, we applied multiple regression analysis for finding the degree of correlation between two explanatory variables (range 
shift and phenology shift of Himalayan pheasant) and one dependent variable climate warming adopted by Bhattacharya \& Pradhan (2018), using SPSS ver. 21.

\section{Results}

A total of 120 local people, directly associated with the Khangchendzonga Biosphere Reserve, were interviewed using a snowball technique. The respondents agreed upon the factual presence of four Himalayan pheasants, Ithaginis cruentus, Lophophorus impejanus, Lophura leucomelana, and Tragopan satyra, in KBR. The interaction and semi-structured questionnaire-based information divulged that the majority of Himalayan pheasants inhabit the high-altitude areas of the KBR except for Lophura leucomelanos, confining in the subtropical forests to temperate forests of the study area. We primarily confirmed their presence in the KBR through our field surveys. Ithaginis cruentus and Lophophorus impejanus occupy the subalpine-alpine meadows, Tragopan satyra occurs in cold temperate-subalpine forests, and Lophura leucomelanos in the subtropical - temperate forests.

The present status of availability of the Himalayan pheasants was also quantified based on the questionnaire. Respondents perceived the highest availability of Ithaginis cruentus population in the KBR, followed by Lophura leucomelanos, Lophophorus impejanus and Tragopan satyra (Fig. 2 ). The majority of respondents reported a decreasing population trend of the Himalayan pheasants in KBR, except for Ithaginis cruentus. Apart from a few, most of the respondents did not confirm that they saw or encountered any poaching/hunting of the targeted pheasants in KBR. The results revealed that the maximum poaching/hunting pressure was on Lophura leucomelanos in the past decades followed by Tragopan satyra, Ithaginis cruentus, and Lophophorus impejanus (Fig. 2).

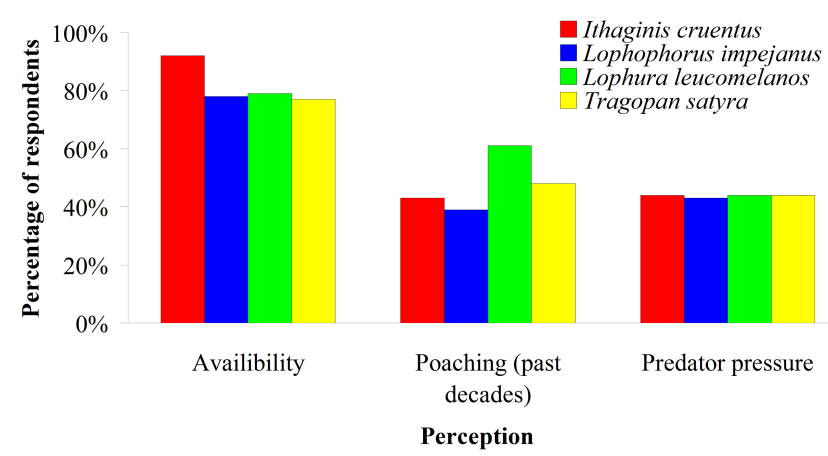

Fig. 2. Respondents' perception based on three studied attributes (availability, poaching and predator pressure) for the targeted Himalayan pheasants.
According to the respondents, the lower altitude species are under pressure of hunting/poaching due to the presence of human settlements at around 1600 $\mathrm{m}$ a.s.l. This could be the main reason for their higher conservation threat. However, such poaching is often limited to fewer instances, as per the interaction with stakeholders. The study also developed the perceptionbased Priority Index of the predators on the Himalayan pheasants. Buteo hemilasius Temminck \& Schlegel, 1844 emerged as the top predator of the Ithaginis cruentus followed by the mammals Vulpes vulpes Linnaeus, 1758, Martes flavigula (Boddaert, 1785), Mustela altaica Pallas, 1811 and others, based on the Priority Index. Similarly, B. hemilasius followed by M. altaica, M. flavigula and $V$. vulpes emerged as the top predators of Lophophorus impejanus. Buteo hemilasius emerged as the top perceived predator for both Tragopan satyra and Lophura leucomelanos, followed by M. flavigula, Canis aureus Linnaeus, 1758 and Herpestes urva Hodgson, 1836.

Respondents strongly agreed that the climate change manifestations such as climate warming (increasing temperature), drying wetlands and springs, and reducing snow cover are more pronounced in Himalayan premises. They perceived that the Himalayan pheasants are shifting their range compared to the last 10-20 years. In their interviews, the respondents highlighted the factors of climate warming, deforestation, food scarcity, vegetation shifting, and habitat disturbance. Moreover, based on the majority respondents, climate warming (rise of temperature and depletion of snow coverage) appeared to be the main causative agent for the range shifts (shifting higher altitude) and phenology shift (earlier breeding time) of the referred pheasants compared to the last few decades. Their forefathers used these Himalayan pheasants for various purposes such as decoration, religious ceremonies, ethnomedicine, healing, and poaching, which emerged in the Priority Index (Fig. 3).

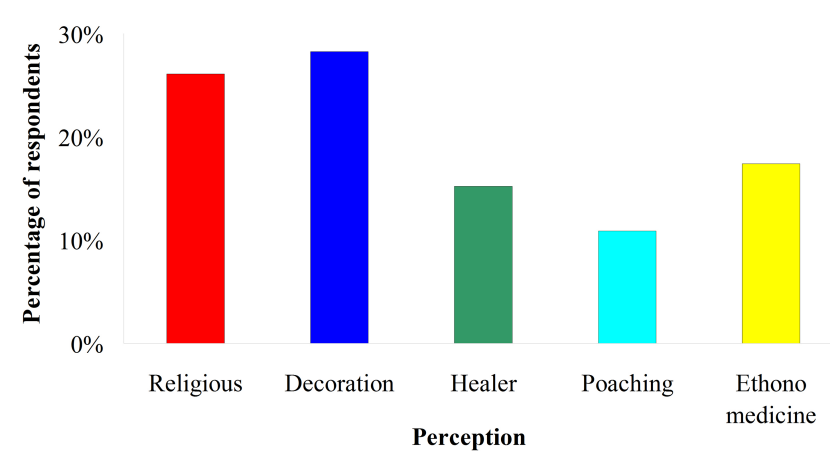

Fig. 3. The respondents' perception on the types of the use of the targeted Himalayan pheasants by their forefathers, expressed as the Priority Index. 
The mean, mode, and median of three variables, climate warming, range shift, and phenology shift were very close. This suggested that these variables are not much of a departure from their normal distribution. The standard deviation was not very high, representing similarity in responses (Table 1).

Results from the analysis of the three explanatory variables of perception (mean and standard error) are represented in Fig. 4. On a scale of 0 to 3 , the respondents' perception was 2.31 for climate warming, followed by 2.15 for range shift, and 1.55 for the phenology shift. The normality of the data tested by Kolmogorov-Smirnova test and Shapiro-Wilk test was found as significant $(\mathrm{p}<0.001)$.

The KMO test demonstrates the adequateness of sample size. The model was fitted as revealed by the $\chi^{2}$-statistic, which emerged significantly beyond $\mathrm{p}<0.001$. The BTS results indicated that the data were appropriate for Principal Component Analysis (Table 2).

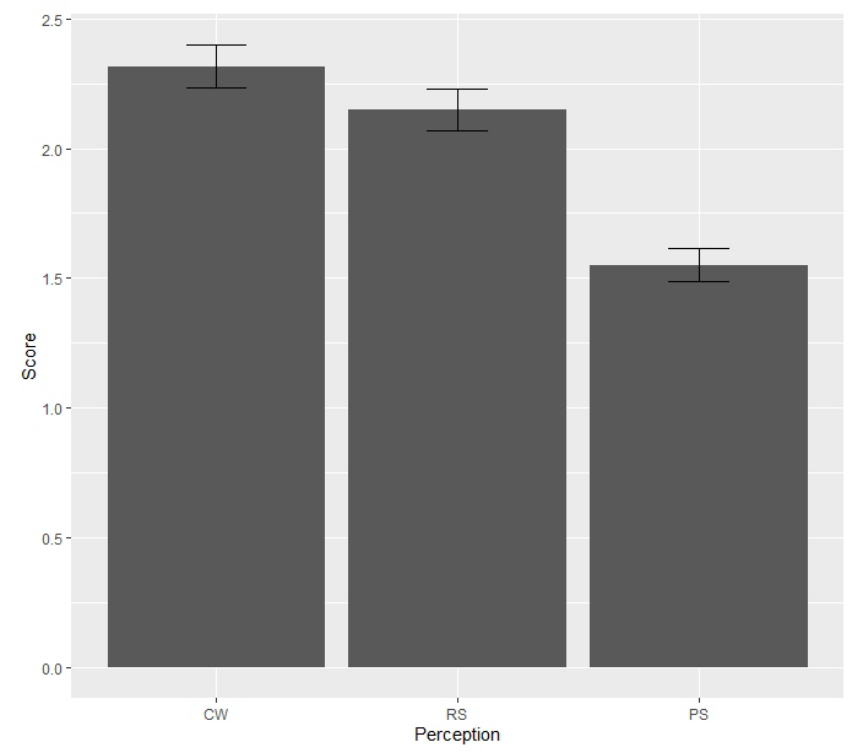

Fig. 4. Mean score bars with standard errors of three explanatory variables for the targeted Himalayan pheasants. Designations: CW - climate warming, RS range shift, PS - phenology shift.

Table 1. Statistics of the three explanatory variables, climate warming, range shift and phenology shift, for the respondents' perception in relation to the targeted Himalayan pheasants

\begin{tabular}{|l|c|c|c|}
\hline Descriptive statistic & $\begin{array}{c}\text { Climate } \\
\text { warming }\end{array}$ & $\begin{array}{c}\text { Range } \\
\text { shift }\end{array}$ & $\begin{array}{c}\text { Phenology } \\
\text { shift }\end{array}$ \\
\hline Mean & 2.31 & 2.15 & 1.55 \\
\hline Median & 3.00 & 2.00 & 1.00 \\
\hline Mode & 3.00 & 3.00 & 1.00 \\
\hline Standard Deviation & 0.89 & 0.87 & 0.70 \\
\hline
\end{tabular}

Table 2. Kaiser-Meyer-Olkin test demonstrating the adequateness of sample size and Barlett Test of Sphericity indicating the appropriateness of data for principal component analysis for the explanatory variables

\begin{tabular}{|l|l|r|}
\hline Kaiser-Meyer-Olkin test of sampling adequacy & 0.680 \\
\hline \multirow{3}{*}{ Bartlett Test of Sphericity } & Approximate $\chi^{2}$ & 135.085 \\
\cline { 2 - 3 } & df & 3 \\
\cline { 2 - 3 } & $\mathrm{p}$ & 0.001 \\
\hline
\end{tabular}

Note: $\mathrm{df}$ - degrees of freedom; $\mathrm{p}$ - significance value

The value of Cronbach's alpha (0.817) was found quite high despite a smaller number of items (three variables) for questionnaire reliability. After establishing the scale reliability and validity, linear regression analysis was found to judge the range shift of the pheasants. Results based on Principal Component Analysis obtained an eigen-value of 2.204 and a variance percentage of $73.47 \%$. The component consists of three variables, namely climate warming, range shift, and phenology shift of the targeted Himalayan pheasants. The regression results establish the correlation between explanatory variables and the dependent variable indicates the overall effect of climate warming (Table 3 ). The results of the regression adequately demonstrate that the goodness of fit was quite acceptable, considering the value, which was significant $(\mathrm{p}<0.001,95.0 \%$ confidence level). Table 3 shows the value of $\mathrm{R}^{2}$, which signifies that the variance $(52 \%)$ in the variable of dependence is explained by given variables of independent or explanatory. It is predicted that climate warming has affected both the range shift and phenology shift of the species. Table 3 shows that the variable of climate warming (dependent variable) significantly influences the overall pheasant range shift (independent variable, $p<0.001$ ), as revealed by the data obtained from the respondents. However, the phenology shift (independent variable) and climate warming of the pheasants did not show significant relation $(\mathrm{p}<0.091)$. The unstandardised coefficient indicates that the independent variables increase by one unit. Then the dependent variables predicted to increase by beta value, i.e. 0.648 for range shift and 0.171 for phenology shift. Similarly, the standardised coefficient indicates the degree of association between independent and dependent variables, i.e. it shows that a strong degree of association exists between climate warming and range shift, compared to phenology shift. 
Table 3. Linear regression for the explanatory variables (climate warming, range shifts, and phenology shifts) of the studied Himalayan pheasants

\begin{tabular}{|c|c|c|c|c|c|}
\hline \multirow{3}{*}{ Model } & \multicolumn{2}{|c|}{$\mathrm{R}$} & $\mathrm{R}^{2}$ & Adjusted $\mathrm{R}^{2}$ & SE \\
\hline & \multicolumn{2}{|c|}{0.742} & 0.524 & 0.516 & 0.61816 \\
\hline & \multicolumn{2}{|c|}{ Unstandardised coefficients } & Standardised coefficients & $\mathrm{t}$ & $\mathrm{p}$ \\
\hline Explanatory variables & $\mathrm{B}$ & SE & Beta & & \\
\hline $\begin{array}{c}\text { Climate warming } \\
\text { (Dependent Variable) }\end{array}$ & 0.660 & 0.160 & - & 4.122 & 0.006 \\
\hline Range shift & 0.648 & 0.079 & 0.638 & 8.154 & 0.001 \\
\hline Phenology shift & 0.171 & 0.100 & 0.134 & 1.707 & 0.091 \\
\hline
\end{tabular}

Note: $\mathrm{SE}$ - standard error, $\mathrm{p}$ - significance value, $\mathrm{t}$ - $\mathrm{t}$-value.

\section{Discussion}

The perception-based information from the respondents suggests that the Khangchendzonga Biosphere Reserve (KBR) has the maximum availability of Ithaginis cruentus, followed by Lophura leucomelanos, Lophophorus impejanus, and Tragopan satyra. Earlier field surveys in KBR indicated similar availability trends for these Himalayan pheasants (Sathyakumar et al., 2010; Chhetri et al., 2017). Nowadays, people more frequently encounter the flocks or individuals of Ithaginis cruentus in KBR, as the KBR experiences reduced anthropogenic pressures in comparison with the situation a few decades ago. This could be a reason that the habitats of pheasants are being restored.

The maximum poaching pressure by their forefathers was demonstrated for Lophura leucomelanos, followed by Tragopan satyra, Ithaginis cruentus, and Lophophorus impejanus. Lophura leucomelanos and Tragopan satyra inhabit the relatively lower altitudinal ranges, where human settlements are close to them, compared to Ithaginis cruentus and Lophophorus impejanus. Therefore, Lophura leucomelanos and Tragopan satyra experience maximum conservation threats. Apart from the anthropogenic pressure, these Himalayan pheasants are killed by various predators (Jia et al., 2005; Kukreti, 2015). Respondents considered equal threats from natural predators for all the pheasants, but it seemed that earlier anthropogenic threat was unequal for the pheasants in the KBR. Historically, tribal communities were living in the forest in harmony with wildlife and used the natural resources sustainably for their livelihood (Gupta \& Guha, 2002; Jyrwa et al., 2020). In a similar way, the indigenous knowledge-based perception results indicated that these Himalayan pheasants were used for various purposes by their forefathers.

The local people inhabiting the transition zone or encountered in movements for their involvement with various jobs and activities in the KBR are often great observers of in-weather variability and biotic distributions, narrative towards climate change risks. It has been reported that the Himalayan region is warming more than the global average, which has significantly impacted the Himalayan biodiversity (Gaire et al., 2014; Socolar et al., 2017; Chhetri et al., 2018). Similar observations were obtained from the respondents based on their perceptions. So, the temperature is a crucial environmental variable that is not stable compared to a few decades ago in the region. Most of the older senior respondents have been experiencing their premise warming due to climate change. The reducing snowfall and snow coverage in their premise are other impacts of climate change in the Himalayas, as per respondents.

Our current study examined how climate change impacted the Himalayan animal groups and their resilience using the perception-based indigenous knowledge taking as model taxa four Himalayan pheasant species. This is important as these cold-adapted species are endemic to the Himalayas and very sensitive to their habitat degradation and climate change and thus acts as an indicator of the forest quality. However, based on indigenous people's perception, these pheasants are shifting in the upward direction along altitudinal gradients of the Himalayan ecosystem due to climate changes, apart from their seasonal migration. Based on the respondents' information, Ithaginis cruentus and Lophophorus impejanus exhibit seasonal migration in the summer and winter seasons. However, Tragopan satyra and Lophura leucomelanos do not practice seasonal migration within the study area. A similar result was obtained for these pheasants during field study carried on landscape level (Sathyakumar et al., 2010; Chhetri et al., 2017). Based on perception knowledge on the high-altitude bird communities, besides the Himalayan regions, the Galliformes seemed to be more threatened by anthropogenic pressures (Chamberlain et al., 2016).

Indigenous people have had long-term information about their local biodiversity which is passed down from their forefathers. Also, the local perception largely relies on their long-term personal experiences and 
is considered more extensive and acute than the scientific and media dialogue on climate change around the world (Marin \& Berkes, 2013). Moreover, the local people's knowledge of climate change is reliable with scientific observations (Perez et al., 2010). Nowadays, traditional knowledge and perception-based information are considered as the baseline data to the modern scientific communities, because they gather the longterm experience about the natural elements in their surrounding landscapes. Unfortunately, most of the traditional knowledge and people's long-time experience and observations are rapidly vanishing in the lack of proper documentation. People's perception is useful to formulate appropriate strategies for avian conservation. However, people's perceptions of birds may vary with respondents (Clergeau et al., 2001). In our study, people's perception of the pheasants also slightly varied with the respondents.

The global mean annual temperature is increasing, though unevenly distributed worldwide. But some of the maximum average temperatures are increasing in the high-mountain ecosystems (Pachauri et al., 2014). Similarly, the heat-sensitive populations of plants (thermophilic) are seen increasing along high-altitudinal gradients (Gottfried et al., 2012; Gaire et al., 2014). In our study area, the respondents experienced changes in local climate over time, especially as the temperature is increasing and the snowfall and snow covers are reducing along the high-altitude mountain areas. This means that the local communities are the witness of changes in natural elements of their surroundings in KBR. This information can be considered as the baseline data, offering vital clues for further conservation research. Climate changes do not only affect the abiotic components (temperature, rainfall, water resource, snowfall) but also equally impact the biotic components, like range shift and phenology shift of birds (Socolar et al., 2017; Chhetri et al., 2018, 2021). The temperature of the Himalayas has increased by $0.74^{\circ} \mathrm{C}$ over the last 100 years (Du et al., 2004; Solomon et al., 2007). Even over the 100 years, it is predicted to rise land's temperature by $1.2-4.5^{\circ} \mathrm{C}$ (Stocker et al., 2013). Further, the highest temperature ascents in India with $1^{\circ} \mathrm{C}$ in winter to $1.1^{\circ} \mathrm{C}$ in post-monsoon are compared to the last 100 years (Dash et al., 2007).

In the current study, most of the respondents related the climate-driven range shift of the Himalayan pheasants with the depletion of snow cover in the Himalayan region. The respondents' data further indicate that the variables of climate warming attribute significantly influenced $(p<0.000)$ the overall Himalayan pheasant range shift. However, the model did not show a significant relationship between climate change and pheasants' phenology shift. It could be the reason that the range shifting was easily noticeable rather than the phenology shifting of the Himalayan pheasants in forests due to certain constraints. Several studies have reported that the Himalayan biodiversity is under threat of the current rate of climate changes; as a result, many Himalayan species are shifting their range towards higher altitude and latitude, including Himalayan pheasants (Acharya \& Vijayan, 2010; Gaire et al., 2014; Chhetri et al., 2017, 2018; Subba et al., 2018; Singh et al., 2020). Even some endemic Himalayan pheasants, like Tragopan, are range-restricted vulnerable birds, and any alternations in their environmental variables may impair their survival (Chhetri et al., 2017; Singh et al., 2020). Therefore, our study addressing the issues based on people's perception towards biodiversity of the eastern Himalayan region could be useful to formulate strategies by the conservation directives to mitigate the current rate of climate change in the Himalayas.

\section{Conclusions}

The impact of global climate changes does widely threaten biodiversity and ecosystem services. By altering behaviour, phenology, and shifting geographic ranges, the species have been counteracting to such effects (Weiskopf et al., 2020). However, the survival of the studied species in response to climate warming would solely rely on their adaptive power by their shifting towards cooler regions or by changing phenology. The result of this perception-based study on Himalayan pheasants, conducted in the Khangchendzonga Biosphere Reserve in Eastern Himalaya, is crucial for conservation directives to better understand the changing trends of environmental factors and biodiversity for the current rate of global climate changes, and in developing suitable conservation strategies for habitat management of the species in the future perspective. Our study will also help to address the biodiversity conservation complications of the Himalayan region where scientific explorations are not sufficiently attained, by enabling researchers to initiate deeper explorations in the future. Therefore, we recommend the long-term monitoring programme for the Himalayan pheasants based on their range and phenology shifts before their survival gets jeopardised towards the species extinction.

\section{Acknowledgements}

The authors thank former Director (Dr. P.P. Dhyani) of the G.B. Pant National Institute of Himalayan Environment and Sustainable Development (India) for providing neces- 
sary facilities. Appreciation extended to the field support of officials and field workers of the State Forest Departments, Governments of Sikkim (India).

\section{Supporting Information}

Photographs of the selected Himalayan pheasant species and their potential habitats in the core zone of Khangchendzonga Biosphere Reserve (Electronic Supplement. The selected Himalayan pheasant species and their potential habitats in the Khangchendzonga Biosphere Reserve, with short commentaries) may be found in the Supporting Information.

\section{References}

Acharya B.K., Vijayan L. 2010. Status and distribution of endemic and threatened birds of the eastern Himalaya in Sikkim, India. Journal of Threatened Taxa 2(2): 685689. DOI: 10.11609/JoTT.o2257.685-9

Badola H.K. 2017. Biocultural knowledge for biodiversity conservation: some Himalayan endorsements. Biodiversity 18(4): 212-218. DOI: 10.1080/14888386.2017.1410444

Badola H.K., Subba J.B. 2012. Khangchendzonga Biosphere Reserve (Sikkim). In: L.M.S. Palni, R.S. Rawal, R.K. Rai, S.V. Reddy (Eds.): Compendium on Indian Biosphere Reserves: Progression During Two Decades of Conservation. Kosi-Almora: Kosi-Almora and Ministry of Environment and Forests. P. 133-142.

Barnard P., Thuiller W. 2008. Introduction. Global change and biodiversity: future challenges. Biology Letters 4(5): 553-555. DOI: $10.1098 / \mathrm{rsbl} .2008 .0374$

Bennett N.J. 2016. Using perceptions as evidence to improve conservation and environmental management. Conservation Biology 30(3): 582-592. DOI: 10.1111/cobi.12681

Berkes F., Colding J., Folke C. 2000. Rediscovery of traditional ecological knowledge as adaptive management. Ecological Applications 10(5): 1251-1262. DOI: 10.1890/1051-0761(2000)010[1251:ROTEKA]2.0.CO;2

Bhattacharya D., Pradhan S. 2018. Perception of tour operators on the sustainability of home stay projects: an empirical investigation. International Journal of Basic and Applied Research 8(6): 1207-1217.

Byg A., Salick J. 2009. Local perspectives on a global phenomenon - climate change in Eastern Tibetan villages. Global Environmental Change 19(2): 156166. DOI: 10.1016/j.gloenvcha.2009.01.010

Chamberlain D.E., Pedrini P., Brambilla M., Rolando A., Girardello M. 2016. Identifying key conservation threats to alpine birds through expert knowledge. PeerJ 4: e1723. DOI: $10.7717 /$ peerj.1723

Chaudhary P., Rai S., Wangdi S., Mao A., Rehman N., Chettri S., Bawa K.S. 2011. Consistency of local perceptions of climate change in the Kangchenjunga Himalaya landscape. Current Science 101(4): 504-513.

Chhetri B., Badola H.K., Barat S. 2017. Ecological study of Satyr Tragopan (Tragopan satyra) in SikkimIndia: a threatened bird species of Eastern Himalaya. International Journal of Recent Scientific Research 8(9): 20362-20368. DOI: 10.24327/ijrsr.2017.0809.0880
Chhetri B., Badola H.K., Barat S. 2018. Predicting climatedriven habitat shifting of the near threatened Satyr tragopan (Tragopan satyra; Galliformes) in the Himalayas. Avian Biology Research 11(4): 221-230. DOI: $10.3184 / 175815618 X 15316676114070$

Chhetri B., Badola H.K., Barat S. 2021. Modelling climate change impacts on distribution of Himalayan pheasants. Ecological Indicators 123: 107368. DOI: 10.1016/j. ecolind.2021.107368

Clergeau P., Mennechez G., Sauvage A., Lemoine A. 2001. Human perception and appreciation of birds: A motivation for wildlife conservation in urban environments of France. In: In: J.M. Marzluff, R. Bowman, R. Donnelly (Eds.): Avian ecology and conservation in an urbanizing world. Boston, USA: Springer. P. 69-88. DOI: 10.1007/978-1-4615-1531-9_4

Crane D.R., Busby D.M., Larson J.H. 1991. A factor analysis of the dyadic adjustment scale with distressed and nondistressed couples. American Journal of Family Therapy 19(1): 60-66.DOI: 10.1080/01926189108250835

Dash S.K., Jenamani R.K., Kalsi S.R., Panda S.K. 2007. Some evidence of climate change in twentieth-century India. Climatic Change 85(3): 299-321. DOI: 10.1007/ s10584-007-9305-9

Du M.Y, Kawashima S., Yonemura S., Zhang X.Z., Chen S.B. 2004. Mutual influence between human activities and climate change in the Tibetan plateau during recent years. Global and Planetary Change 41(3-4): 241-249. DOI: $10.1016 /$ j.gloplacha.2004.01.010

Fisher M., Chaudhury M., McCusker B. 2010. Do forests help rural households adapt to climate variability? Evidence from Southern Malawi. World Development 38(9): 1241-1250. DOI: 10.1016/j.worlddev.2010.03.005

Gaire N.P., Koirala M., Bhuju D.R., Borgaonkar H.P. 2014. Treeline dynamics with climate change at the central Nepal Himalaya. Climate of the Past 10(4): 1277-1290. DOI: $10.5194 / \mathrm{cp}-10-1277-2014$

Gentili R., Badola H.K., Birks H.J. 2015. Alpine biodiversity and refugia in a changing climate. Biodiversity 16(4): 193-195. DOI: 10.1080/14888386.2015.1117023

Gliem J.A., Gliem R.R. 2003. Calculating, interpreting, and reporting Cronbach's alpha reliability coefficient for Likerttype scales. In: Midwest Research-to-Practice Conference in Adult, Continuing, and Community Education. Columbus, USA: Ohio State University. P. 82-88.

Gottfried M., Pauli H., Futschik A., Akhalkatsi M., Barančok P., Alonso J.L.B., Coldea G., Dick J., Erschbamer B., Fernández Calzado M.R., Kazakis G., Krajči J., Larsson P., Mallaun M., Michelsen O., Moiseev D., Moiseev P., Molau U., Merzouki A., Nagy L., Nakhutsrishvili G., Pedersen B., Pelino G., Puscas M., Rossi G., Stanisci A., Theurillat J.P., Tomaselli M., Villar L., Vittoz P., Vogiatzakis I., Grabherr G. 2012. Continent-wide response of mountain vegetation to climate change. Nature Climate Change 2(2): 111-115. DOI: 10.1038/nclimate1329

Gupta A., Guha K. 2002. Tradition and conservation in northeastern India: an ethical analysis. Eubios 12(1): 15-18.

Ives J. 2004. Himalayan perceptions: Environmental change and the well-being of mountain peoples. Vol. 6. London and New York: Routledge Taylor \& Francis Group. 265 p. 
Jia F., Wang N., Zheng G. 2005. Winter habitat requirements of White Eared-pheasant Crossoptilon crossoptilon and Blood Pheasant Ithaginis cruentus in south-west China. Bird Conservation International 15(3): 303-312. DOI: 10.1017/S095927090500047X

Jyrwa J.D., Joshi B.D., Ghosh A., Mayi Y., Nipa M., Anga N., Pali M., Thakur M., Chandra K., Sharma L.K. 2020. Dimensions of changing perception towards wildlife conservation in East Siang district of Arunachal Pradesh, Eastern Himalayas. Global Ecology and Conservation 24: e01265. DOI: 10.1016/j.gecco.2020.e01265

Kukreti M. 2015. Ecology of wide spread white crested kaleej pheasant Lophura leucomelanos hamiltoni (gray) in Garhwal Himalaya, India. Journal of Global Biosciences 4(1): 1245-1249.

Maggini R., Lehmann A., Kéry M., Schmid H., Beniston M., Jenni L., Zbinden N. 2011. Are Swiss birds tracking climate change?: Detecting elevational shifts using response curve shapes. Ecological Modelling 222(1): 21-32. DOI: 10.1016/j.ecolmodel.2010.09.010

Marin A., Berkes F. 2013. Local people's accounts of climate change: to what extent are they influenced by the media? Wiley Interdisciplinary Reviews: Climate Change 4(1): 1-8. DOI: 10.1002/wcc.199

Negi V.S., Maikhuri R.K., Pharswan D., Thakur S., Dhyani P.P. 2017. Climate change impact in the Western Himalaya: people's perception and adaptive strategies. Journal of Mountain Science 14(2): 403-416. DOI: 10.1007/s11629-015-3814-1

Norusis M.J. 1985. SPSSX advanced statistic guide. New York: McGraw-Hill. 505 p.

Olawale F., Garwe D. 2010. Obstacles to the growth of new SMEs in South Africa: A principal component analysis approach. African Journal of Business Management 4(5): 729-738.

Pachauri R.K., Allen M.R., Barros V.R., Broome J., Cramer W., Christ R., Church J.A., Clarke L., Dahe Q., Dasgupta P., Dubash N.K. 2014. Climate change 2014: synthesis report. Contribution of Working Groups I, II and III to the fifth assessment report of the Intergovernmental Panel on Climate Change. Geneva: Intergovernmental Panel on Climate Change. $151 \mathrm{p}$.

Pandey A., Badola H.K., Rai S., Singh S.P. 2018. Timberline structure and woody taxa regeneration towards treeline along latitudinal gradients in Khangchendzonga National Park, Eastern Himalaya. PLoS ONE 13(11): e0207762. DOI: 10.1371/journal.pone.0207762

Perez C., Nicklin C., Dangles O., Vanek S., Sherwood S., Halloy S., Garrett K., Forbes G. 2010. Climate change in the high Andes: implications and adaptation strategies for small-scale farmers. International Journal of Environmental, Cultural, Economic, and Social Sustainability: Annual Review 6(5): 71-88. DOI: 10.18848/1832-2077/CGP/v06i05/54835

R Core Team. 2019. R: A language and environment for statistical computing. Vienna, Austria: R Foundation for Statistical Computing. Available from https://www.R-project.org/

Sánchez-Mercado A., Blanco O., Sucre-Smith B., BriceñoLinares J.M., Peláez C., Rodríguez J.P. 2020. Using Peoples' Perceptions to Improve Conservation Programs:
The Yellow-Shouldered Amazon in Venezuela. Diversity 12(9): 342. DOI: 10.3390/d12090342

Saroar M.M., Routray J.K. 2012. Impacts of climatic disasters in coastal Bangladesh: why does private adaptive capacity differ? Regional Environmental Change 12(1): 169-190. DOI: 10.1007/s10113-011-0247-4

Sathyakumar S., Poudyal K., Bhattacharya T., Bashir T. 2010. Galliformes of Khangchendzonga Biosphere Reserve, Sikkim, India. In: M.L. Arrawatia, S. Tambe (Eds.): Biodiversity of Sikkim - Exploring and Conserving a Global Hotspot. Gangtok: Government of Sikkim. P. 301-315.

Singh H., Kumar N., Kumar M., Singh R. 2020. Modelling habitat suitability of western tragopan (Tragopan melanocephalus) a range-restricted vulnerable bird species of the Himalayan region, in response to climate change. Climate Risk Management 29: 100241. DOI: 10.1016/j.crm.2020.100241

Socolar J.B., Epanchin P.N., Beissinger S.R., Tingley M.W. 2017. Phenological shifts conserve thermal niches in North American birds and reshape expectations for climate-driven range shifts. Proceedings of the National Academy of Sciences of the United States of America 114(49): 12976-12981. DOI: 10.1073/pnas.1705897114

Solomon S., Qin D., Manning M., Chen Z., Marquis M., Averyt K.B., Tignor M., Miller H.L. 2007. Climate change 2007: The physical science basis: Fifth assessment report of the Intergovernmental Panel on Climate Change. Cambridge: Cambridge University Press. 989 p.

Stocker T.F., Qin D., Plattner G.K., Tignor M., Allen S.K., Boschung J., Nauels A., Xia Y., Bex V., Midgley P.M. 2013. Climate change 2013. The physical science basis: Fifth assessment report of the Intergovernmental Panel on Climate Change. Geneva: Intergovernmental Panel on Climate Change. 1535 p.

Subba B., Sen S., Ravikanth G., Nobis M.P. 2018. Direct modelling of limited migration improves projected distributions of Himalayan amphibians under climate change. Biological Conservation 227: 352-360. DOI: 10.1016/j.biocon.2018.09.035

Vignola R., Koellner T., Scholz R.W., McDaniels T.L. 2010. Decision-making by farmers regarding ecosystem services: factors affecting soil conservation efforts in Costa Rica. Land Use Policy 27(4): 1132-1142. DOI: 10.1016/j.landusepol.2010.03.003

Vogt K.A., Beard K.H., Hammann S., O’Hara Palmiotto J., Vogt D.J., Scatena F.N., Hecht B.P. 2002. Indigenous knowledge informing management of tropical forests: the link between rhythms in plant secondary chemistry and lunar cycles. Ambio 31(6): 485-490. DOI: 10.1579/0044-7447-31.6.485

Weiskopf S.R., Rubenstein M.A., Crozier L.G., Gaichas S., Griffis R., Halofsky J.E., Hyde K.J.W., Morelli T.L., Morisette J.T., Muñoz R.C., Pershing A.J., Peterson D.L., Poudel R., Staudinger M.D., Sutton-Grier A.E., Thompson L., Vose J., Weltzin J.F., Whyte K.P. 2020. Climate change effects on biodiversity, ecosystems, ecosystem services, and natural resource management in the United States. Science of The Total Environment 733: 137782. DOI: 10.1016/j.scitotenv.2020.137782 


\title{
КАК ЛЮДИ ВОСПРИНИМАЮТ УСТОЙЧИВОСТЬ ГИМАЛАЙСКИХ ФАЗАНОВ (РНАSIANIDАЕ) К ПОТЕПЛЕНИЮ КЛИМАТА В ВОСТОЧНЫХ ГИМАЛАЯХ
}

\author{
Б. Чхетри ${ }^{1,2} \mathbb{D}$, Г. К. Бадола ${ }^{1,3, * \mathbb{D}}$, С. Барат ${ }^{4}$ \\ ${ }^{1}$ Наииональный институт устойчивости окружающей среды Гималаев имени Г.Б. Панта, Индия \\ *e-mail: hkbadola@gmail.com \\ ${ }^{2}$ Мемориальный университет Шри Рамасами в Сиккиме, Индия \\ ${ }^{3}$ Сэйлок Фэйз 2, Дженерал Махадев Сингх Роад, Дехрадун, Индия \\ ${ }^{4}$ Университет Северной Бенгалии, Индия
}

\begin{abstract}
В концепции воздействия изменения климата на биоразнообразие Гималаев большое внимание уделяется пониманию взаимосвязей между коренными народами и окружающей средой. В литературе явен недостаток информации о последствиях изменения климата для биоразнообразия Гималаев из-за отсутствия данных долговременных исследований. Поэтому инструменты восприятия используются для освещения воздействия изменения климата на биоразнообразие Гималаев на основе знаний местного населения об окружающей среде. Мы использовали метод «снежного кома» (snowball), чтобы понять знания коренного населения, реакцию и их восприятие гималайских фазанов (Ithaginis cruentus, Lophophorus impejanus, Lophura leucomelanos и Tragopan satyra) в связи с изменением климата в Восточных Гималаях. Мы провели тематическое исследование, изучив восприятие людей в биосферном заповеднике Хангчендзонга и его окрестностях. Результаты показали, что потепление климата более выражено в районе Гималаев, что значительно повлияло на гималайских фазанов. Надежность анкеты проверялась с помощью теста альфа Кронбаха. Значение его было довольно высоким, несмотря на небольшое количество (три) переменных. Установив масштабную надежность и достоверность данных, линейный регрессионный анализ оказался подходящим для оценки сдвига ареала фазанов. Регрессионный анализ показал, что степень соответствия была вполне приемлемой, учитывая значение F-критерия Фишера; потепление климата значительно повлияло на общий сдвиг ареала фазанов, как показали данные, полученные от респондентов $(\mathrm{p}<0.001)$. Это исследование позволит понять влияние изменения климата на биоразнообразие Гималаев и уделить больше внимания находящимся под угрозой исчезновения и узкоареальным эндемичным видам Гималаев прежде, чем они окажутся на грани исчезновения.
\end{abstract}

Ключевые слова: Galliformes, знания коренных народов, изменение климата, ограниченный ареал, сохранение, эндемичный вид 